\section{Purification and Properties of Gitrus natsudaidai Pectinesterase $\mathrm{e}^{\dagger}$}

\author{
Masatoshi MANABE \\ College of Agriculture, Kagawa University, \\ Kagawa, Japan
}

Received September 20, 1972

Pectinesterase (PE, EC. 3.1.1.11) is well-known to occur widely in many higher plants, especially in alfalfa, ${ }^{1 /}$ citrus fruits ${ }^{2,31}$ and tomatoes." ${ }^{11}$ The properties of PE from plant sources have been reported by many investigators, but most of the investigations were performed with crude or partially purified enzymes. Nakagawa et al. have recently obtained a purified PE from tomato. ${ }^{5}$ In the course of the studies on the derivatives of pectic substance, the author intended to prepare purified PE from citrus fruits in order to investigate hydrolysis of the ester derivatives of pectic acid with PE. The experiments herein described concern the preparation and properties of a purified PE from Citrus natsudaidai. The investigation on the hydrolytic behavior of the purified enzyme toward the ester derivatives of pectic acid will be reported elsewhere.

Materials. Natsudaidai (Citrus natsudaidai HAYATA, cv. Kawanowase) used in this study was sampled from the Experimental Field, College of Agriculture, Kagawa University.

Citrus pectin (Sunkist Groweres Inc., Rapid Set 150 jelly grade) was used as a substrate. The pectin was purified to remove contaminating materials with $70 \%$ of hot ethanol (at $80^{\circ} \mathrm{C}$, once) and then with cold ethanol (at room temperature, five times). After treating with absolute ethanol and acetone, it was dried in vacuo at $45^{\circ} \mathrm{C}$. The esterification degree of the purified pectin was $64.3 \%$.

Isolation and purification. Natsudaidai was cut in half and squeezed with a hand reamer. The residual tissue was sliced into pieces and homogenized with an excess of cold water for $2 \mathrm{~min}$ in a Waring blendor. The homogenate was squeezed out through cotton cloth. Crude PE was extracted by soaking the homogenized pulp in $1.0 \mathrm{M}$ potassium phosphate buffer, pH 7.5 , for $60 \mathrm{~min}$ at $0^{\circ} \mathrm{C}$. The extract was centrifuged, and the clear supernatant obtained was subjected to the purification procedure as shown in Fig. 1. The experiments were all performed in a cold room at $0^{\circ} \mathrm{C}$. The dialysis of $\mathrm{PE}$ was all conducted against

$t$ Studies on the Derivatives of Pectic Substances. Part IV. The previous paper, M. Manabe, Nippon Nogeikagaku Kaishi, 46, 185 (1972).
$0.01 \mathrm{M}$ potassium phosphate buffer at $\mathrm{pH} 7.5$ for $24 \mathrm{hr}$, and centrifugation was carried out at $8000 \mathrm{rpm}$ for $10 \mathrm{~min}$.

First, to the crude PE extract at pH 7.5, ammonium sulfate was added to $20 \%$ saturation. After standing for $10 \mathrm{~min}$, the precipitate formed was removed by centrifugation and discarded. Ammonium sulfate was added to the supernatant liquid to $80 \%$ saturation. After standing for $1 \mathrm{hr}$, the resulting precipitate was removed by centrifugation and dissolved in a small amount of water. The solution was dialyzed against potassium phosphate buffer The dialyzate was then applied to a DEAE-cellulose column which had been equilibrated with $0.01 \mathrm{M}$ potassium phosphate buffer at $\mathrm{pH} 7.5$.

Figure 2 shows the chromatographic patterns of the PE on DEAE-cellulose column. PE activity was assayed by a modification of the method described by Kertesz. ${ }^{6}$ One unit of PE activity was expressed as the amount of enzyme which catalyzed the formation of $2 \times 10^{-5}$ moles of the free carboxyl group per min according to the method described by Nakagawa et al. ${ }^{5}$ Protein content was determined spectrophotometrically by the method of Lowry et al., ${ }^{71}$ using $a$-L-arabinofuranosidase $\mathrm{e}^{8}$ as standard. A great part of the PE flowed out with $0.01 \mathrm{M}$ potassium phosphate buffer, $\mathrm{pH}$ 7.5. The active fractions were combined, and ammonium sulfate was added to $30 \%$ saturation. After standing for $10 \mathrm{~min}$, the precipitate formed was removed by centrifugation and discarded. The ammonium sulfate concentration was then increased to $80 \%$ saturation. After standing for $1 \mathrm{hr}$, the resulting precipitate was collected by centrifugation and dissolved in a small amount of water. The solution was dialyzed and the dialyzate was applied to a Sephadex G-100 column which had been equilibrated with $0.01 \mathrm{M}$ potassium phosphate buffer, $\mathrm{pH} 7.5$ (Fig. 3). The active fractions were combined, and ammonium sulfate was added to $40 \%$ saturation. After standing for $10 \mathrm{~min}$, the resulting precipitate was removed by centrifugation and discarded. The ammonium sulfate concentration was then increased to $80 \%$ saturation. After standing for $1 \mathrm{hr}$, the resulting precipitate was collected by centrifugation. The precipitate was dissolved in a small amount of water and dialyzed. The dialyzate was once more subjected to gel filtration on a Sephadex G-100 column (Fig. 4). The active fractions were combined, and ammonium sulfate was added to $80 \%$ saturation. After standing for $1 \mathrm{hr}$, the resulting precipitate was removed by centrifugation. The precipitate was dissolved in a small amount of water and dialyzed. Table I summerizes the purification procedure. The PE solution thus obtained had approximately 460-fold higher specific activity than the original extract. A portion of the purified PE solution was dried by freez- 


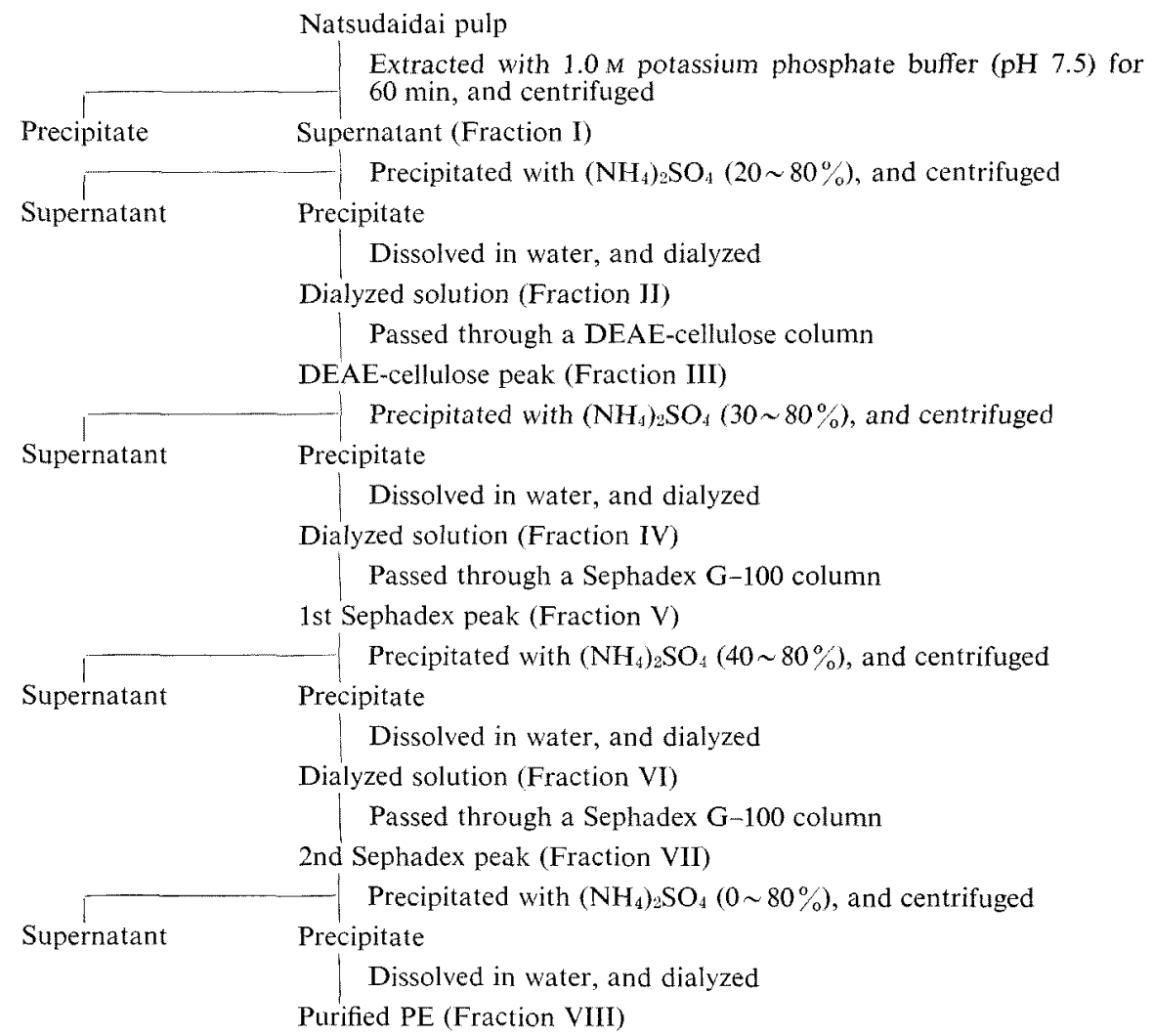

FIG. 1. Purification Procedure for Natsudaidai PE.

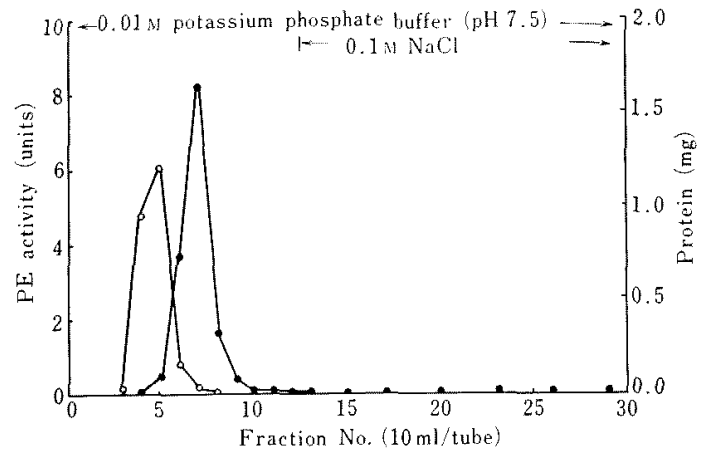

FIG. 2. Chromatography of Natsudaidai PE on DEAE-cellulose Column.

Crude PE solution $(0.7 \mathrm{ml})$ was applied on a column $(1.5 \times 20 \mathrm{~cm})$ equilibrated beforehand with $0.01 \mathrm{M}$ potassium phosphate buffer $\mathrm{pH} 7.5$. Flow rate was $20 \mathrm{ml} / \mathrm{hr}$.

$\mathrm{O}-\mathrm{O}, \mathrm{PE}$ activity;

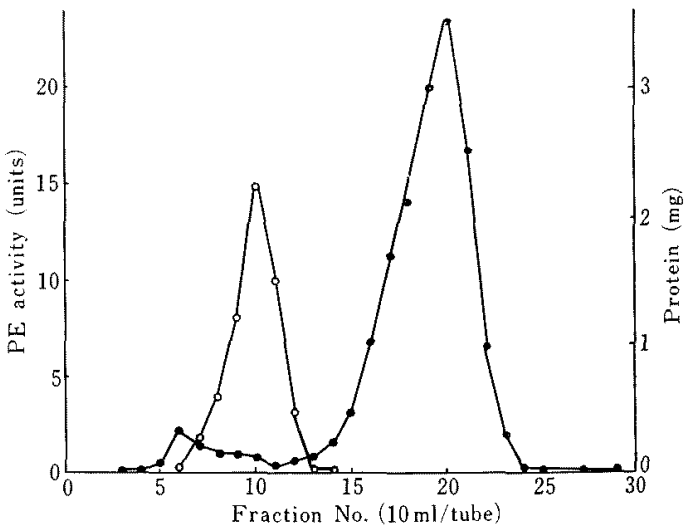

FIG. 3. Chromatography of Natsudaidai PE on Sephadex G-100 (1st) Column.

Dialyzed PE solution $(5 \mathrm{ml})$ after precipitation with $\left(\mathrm{NH}_{4}\right)_{2} \mathrm{SO}_{4}(30 \sim 80 \%)$ was applied on a column $(1.8 \times$ $50 \mathrm{~cm}$ ). Elution was performed with $0.01 \mathrm{M}$ potassium phosphate buffer. Flow rate was $20 \mathrm{ml} / \mathrm{hr}$. $\mathrm{O}-\mathrm{O}, \mathrm{PE}$ activity; $-\bullet$, Protein 
Table I. Purification Procedure of Pectinesterase

\begin{tabular}{lccrcc}
\hline Step of purification & $\begin{array}{c}\text { Volume } \\
(\mathrm{ml})\end{array}$ & $\begin{array}{c}\text { Total } \\
\text { activity } \\
\text { (unit) }\end{array}$ & $\begin{array}{c}\text { Total } \\
\text { protein } \\
(\mathrm{mg})\end{array}$ & $\begin{array}{c}\text { Specific } \\
\text { activity } \\
\text { (unit/mg) }\end{array}$ & $\begin{array}{c}\text { Enzyme } \\
\text { yield } \\
(\%)\end{array}$ \\
\hline Crude extract & 2960 & 32,678 & 136,278 & 0.24 & 100.0 \\
Dialyzed solution & 274 & 15,946 & 18,378 & 0.87 & 48.8 \\
DEAE-cellulose peak & 614 & 8,792 & 6,604 & 1.33 & 26.9 \\
Dialyzed solution & 108 & 9,950 & 3,448 & 2.89 & 30.4 \\
Sephadex G-100 peak & 580 & 8,091 & 168 & 48.19 & 24.8 \\
Dialyzed solution & 33 & 5,502 & 74 & 74.35 & 16.8 \\
Sephadex G-100 peak & 218 & 3,946 & 36 & 109.60 & 12.1 \\
Purified solution & 36 & 3,422 & 31 & 110.39 & 10.5 \\
\hline
\end{tabular}

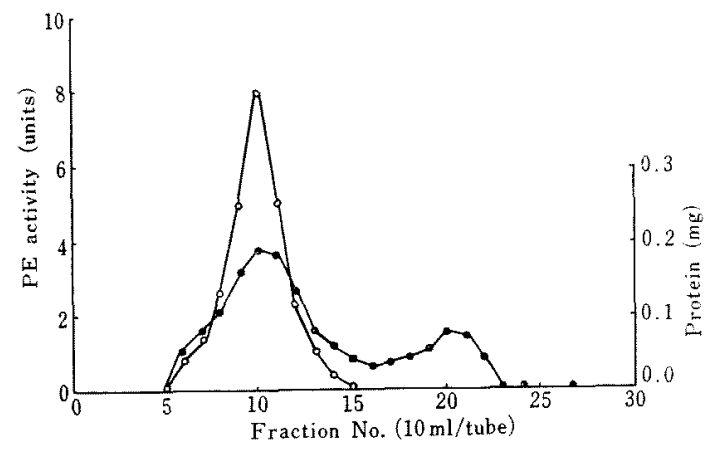

FIG. 4. Rechromatogram of Natsudaidai PE on Sephadex G-100 (2nd) Column.

Dialyzed PE solution $(7 \mathrm{ml})$ after precipitation with $\left(\mathrm{NH}_{4}\right)_{2} \mathrm{SO}_{4} \quad(40 \sim 80 \%)$ was applied on a column $(1.8 \times 50 \mathrm{~cm})$. Elution was performed with $0.01 \mathrm{M}$ potassium phosphate buffer. Flow rate was $20 \mathrm{ml} /$ hr.

$\mathrm{O}-\mathrm{O}, \mathrm{PE}$ activity; - , Protein

ing and pulverized.

Homogeneity. Figure 5 shows the results of the disc electrophoresis in polyacrylamide gel. Disc electrophoresis was carried out by the method of Davis, ${ }^{91}$ with an apparatus from Mitsumi Kagaku Sangyo Co., Ltd. The purified PE showed a single band, but commercial tomato PE did not show such a single band. This fact gives evidence for the homogeneity of the purified Natsudaidai PE.

Amino acid composition. The assay of amino acids was as follows: An amount of $1.51 \mathrm{mg}$ of PE was hydrolyzed in a sealed tube with $2 \mathrm{ml}$ of $6 \mathrm{~N}$ hydrochloric acid (containing $0.4 \%$ of $\beta$-thioglycolic acid) for $24 \mathrm{hr}$ at $120 \mathrm{C}$ and the hydrolyzate was evaporated to dryness in vacuo to remove $\mathrm{HCl}$. The dried amino acids were dissolved in $2 \mathrm{ml}$ of $0.2 \mathrm{M}$ citric acid-sodium citrate buffer, pH 2.2, and analyzed with a Hitachi amino acid analyzer KLA-5. Table II shows the amino

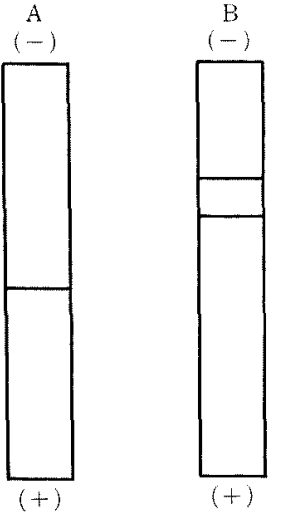

Frg. 5. Disk Electrophoresis of Purified Natsudaidai PE (A) and Commercial Tomato PE (B).

Electrophoresis was performed in $7.5 \%$ polyacrylamide gel at pH 7.5, $2 \mathrm{~mA}$ for $150 \mathrm{~min}$. The sample contained $100 \mu \mathrm{g}$ of protein.

acid composition of the purified Natsudaidai PE. The PE consisted of seventeen kinds of amino acids, and the amounts of aspartic acid, glycine, and alanine were comparatively high. However, cysteic acid, hydroxy proline and cystine were not identified. The content of each amino acid was in agreement with that of the purified tomato PE. ${ }^{101}$

Kinetics of enzyme reaction. Reaction velocity was determined at $30^{\circ} \mathrm{C}$ with double reciplocal plots, ${ }^{11}$ as shown in Fig. 6. The $K / n$ and $V_{\text {max }}$ values were 2.30 (gram per liter) and $4.1 \times 10^{-5}$ (mole $\mathrm{NaOH}$ consumed per $\mathrm{min}$ ), respectively.

Optimal pH. As presented in Fig. 7, optimal pH of the purified Natsudaidai PE was at $\mathrm{pH} 8.0$. On the other hand, crude Natsudaidai, and crude tomato PE (Sigma Chemical Co.) showed no clear optimal pH.

$p H$ stability. Effect of $\mathrm{pH}$ on stability of the purified Natsudaidai PE in $0.01 \mathrm{M}$ citrate-phosphate 
Table II. Amino Acid Compositions of NATSUDAIDAI PE

\begin{tabular}{lc}
\hline \multicolumn{1}{c}{ Amino acid } & $\begin{array}{c}\text { Amino acid } \\
\text { (mmoles/100 } \mathrm{g} \\
\text { protein) }\end{array}$ \\
\hline Tryptophan & 8.47 \\
Lysine & 30.71 \\
Histidine & 8.47 \\
Arginine & 30.00 \\
Aspartic acid & 55.60 \\
Threonine & 40.24 \\
Serine & 41.30 \\
Glutamic acid & 38.66 \\
Proline & 29.66 \\
Glycine & 49.25 \\
Alanine & 51.90 \\
Valine & 38.66 \\
Methionine & 5.29 \\
Isoleucine & 24.36 \\
Leucine & 34.40 \\
Tyrosine & 19.07 \\
Phenylalanine & 21.69 \\
Ammonia & 69.37 \\
\hline
\end{tabular}

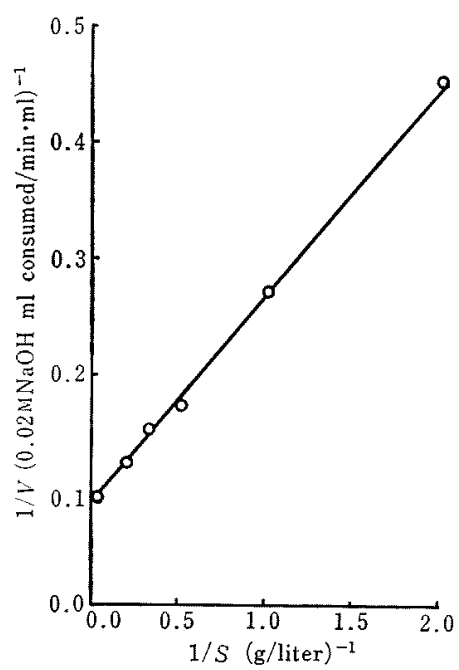

FIg. 6. Lineweaver-Burk Plots for Natsudaidai PE.

buffer solution incubated for $240 \mathrm{~min}$ at $50^{\circ} \mathrm{C}$, is shown in Fig. 8. The PE was unstable at $\mathrm{pH} 3.0$ and 10.0, and completely inactivated within $10 \mathrm{~min}$. At $\mathrm{pH}$ ranged from 5.0 to 8.0 , however, it was considerably stable.

Thermostability. The activity of after incubation at various temperatures for $5 \mathrm{~min}$ and at $\mathrm{pH} 7.5$ was determined. The purified Natsudaidai PE was stable at temperatures below $50^{\circ} \mathrm{C}$ but completely inactivated

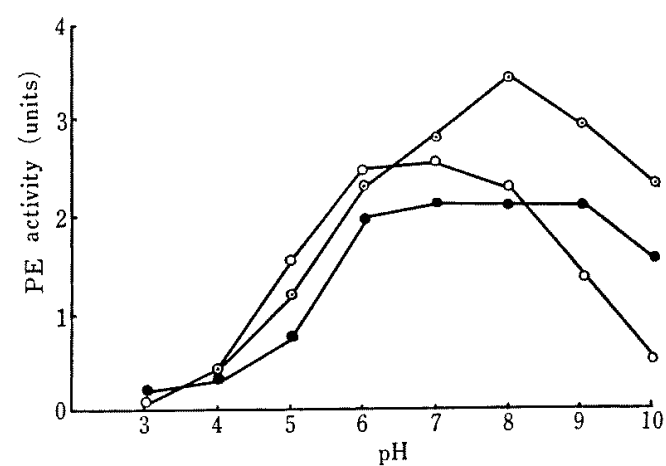

Frg. 7. Effect of pH on Activity of PEs.

$\odot-\odot$, Purified Natsudaidai PE; - - , Crude Natsudaidai $\mathrm{PE} ; \mathrm{O}-\mathrm{O}$, Crude tomato $\mathrm{PE}$

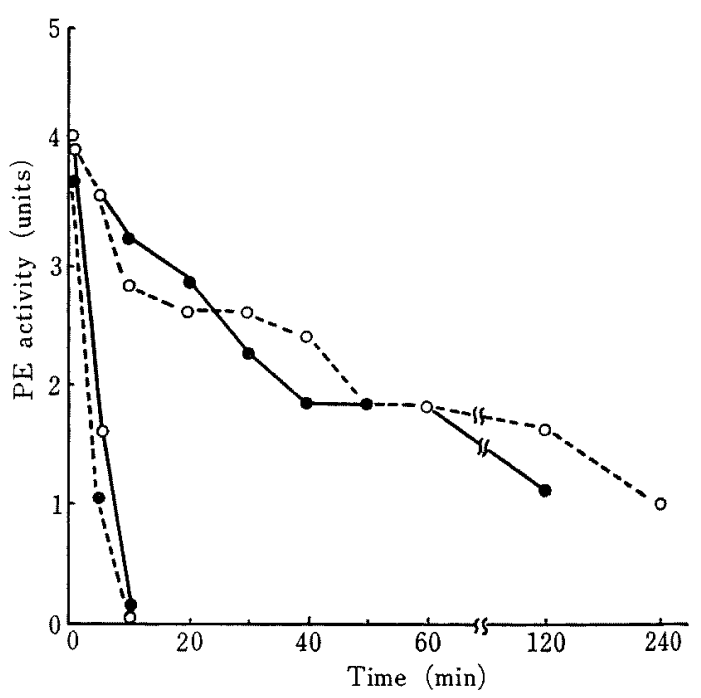

FIG. 8. Effect of pH on Stability of Natsudaidai PE.

$\mathrm{PE}$ was dissolved in $0.01 \mathrm{M}$ citrate- $\mathrm{Na}_{2} \mathrm{HPO}_{4}$ buffer with each $\mathrm{pH}$ and incubated at $50^{\circ} \mathrm{C}$.

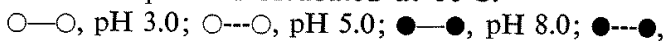
pH 10.0

at $80^{\circ} \mathrm{C}$, as shown in Fig. 5 .

It has been generally known that citrus fruits have only PE among pectolytic enzymes, but tomato fruits exist polygalacturonases in addition to PE. Accordingly, the purification of $\mathrm{PE}$ is considered to be easier in citrus fruits than in tomatoes. On the other hand, Hultin et al. ${ }^{12)}$ obtained three PE fractions from banana pulp by a different extraction procedures. These fraction possess a different kinetic properties. Endo ${ }^{13}$ has separated PEs I and II from a culture extract of Coniothyrium diplodiella, and reported that these enzymes completely lost the activity within $10 \mathrm{~min}$ at $55^{\circ} \mathrm{C}$ and were most active at $\mathrm{pH} 4.5 \sim 5.0$. It seems 


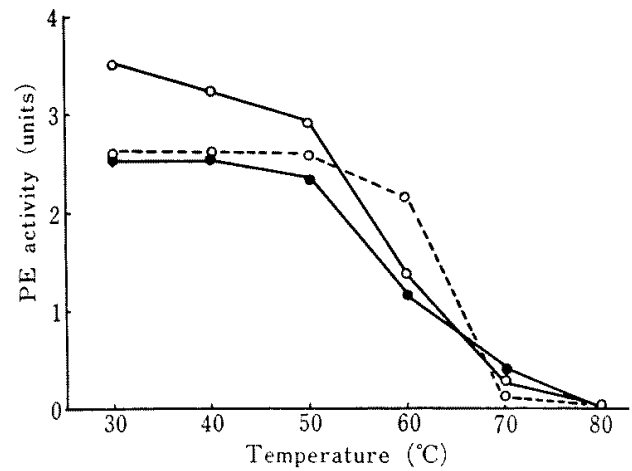

FIG. 9. Effect of Temperature on PE Activity.

Enzyme solution was preincubated in $0.01 \mathrm{M}$ potassium phosphate buffer ( $\mathrm{pH} 7.5$ ) for $5 \mathrm{~min}$ at each temperature and residual activity was determined. $\mathrm{O}-\mathrm{O}$, Purified Natsudaidai PE; $-\bullet$, Crude Natsudaidai PE; $O--O$, Crude tomato $\mathrm{PE}$

that the Natsudaidai PE is somewhat different from the mold PE. ${ }^{13}$

The author wishes to thank Professor K. Onodera, Kyoto University, for his kind guidance and critical reading of the manuscript. Thanks are due to Professor A. Kaji, Kagawa University, for his useful suggestion and discussion. The author thanks Professor T. Tarutani, Kagawa University, for his encouragement. Thanks are also extended to Mr. H. Yamamoto, Kagawa University, for gel electrophoretic analysis and to K. Okajima, Hitachi Ltd., for amino acid analysis.

\section{REFERENCES}

1) H. Lineweaver and G. A. Ballou, Arch. Biochem., 6, 373 (1945).

2) L. R. MacDonnell, E. F. Jansen and H. Lineweaver, ibid., 6, 389 (1945).

3) L. R. MacDonnell, R. Jang, E. F. Jansen and H. Lineweaver, ibid., 28, 260 (1950).

4) R. J. McColloch and Z. I. Kertesz, ibid., 13, 217 (1947).

5) H. Nakagawa, Y. Yanagawa and H. Takehana, Agr. Biol. Chem., 34, 991 (1970).

6) Z. I. Kertesz, "Methods in Enzymology," Vol. I, ed. by S. P. Colowick and N. O. Kaplan, Academic Press Inc., New York, 1955, p. 158.

7) O. H. Lowry, N. J. Rosebrough, A. L. Farr and R. J. Randall, J. Biol. Chem., 193, 265 (1951).

8) A. Kaji and K. Tagawa, Biochim. Biophys. Acta, 207, 456 (1970).

9) B. J. Davis, Ann. New York Acad. Sci., 121, 404 (1964).

10) H. Nakagawa, Y. Yanagawa and H. Takehana, Agr. Biol. Chem., 34, 998 (1970).

11) H. Lineweaver and O. Burk, J. Am. Chem. Soc., 56, 658 (1934).

12) H. O. Hultin, B. Sun and J. Bulger, J. Food Sci., 31, 320 (1966).

13) A. Endo, Agr. Biol. Chem., 28, 757 (1964). 